\title{
Teaching NeuroImages: Spinal intramedullary cysticercosis
}

\author{
The pseudotumoral form
}

Carlos Almeida, Jr., ME,* Gisele Caravina de Almeida, MD, Jorge Alberto Martins Pentiado, Jr.,* and Richard Konichi Dias*

Neurology ${ }^{\circledR}$ 2018;91:e1202-e1203. doi:10.1212/WNL.0000000000006206
Correspondence

R. Konichi Dias

richardkonichi95@gmail.com

Figure $1 \mathrm{MRI}$ shows intramedullary cystic lesion located at T3-T4 level

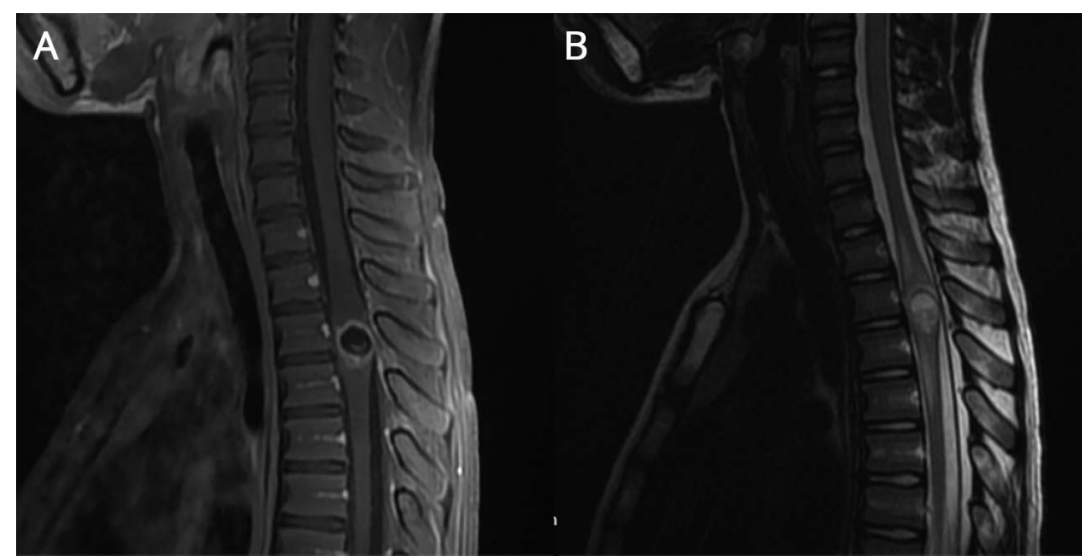

(A) Gadolinium-enhanced sagittal T1. (B) Sagittal T2. MRI shows intramedullary cystic lesion located at T3-T4 level, with a thick wall and contrast enhancement, associated with adjacent vasogenic edema. The lesion features hyperintense signal on T2 (due to proteinaceous content of the fluid) with a streak of hyperintensity on T1 (which could indicate the degenerative scolex), compatible with the colloidal phase of cysticercosis (mimicking a neoplastic lesion).

A 10-year-old boy was admitted to the hospital with decreased muscle strength in lower limbs. Physical examination revealed isolated spastic crural paraparesis. MRI of the thoracic spine demonstrated a cystic intramedullary lesion (figure 1). The patient underwent complete microsurgical resection of the lesion. Anatomopathologic report (figure 2) confirmed cysticercosis. Intramedullary cysticercosis is a rare parasitic infection caused by Taenia solium $(0.7 \%-5.8 \%$ of all patients with neurocysticercosis $){ }^{1}$ This presentation is usually underdiagnosed because, in degeneration phases, it is difficult to visualize the parasite in the MRI, mainly the scolex, and immunologic tests are negative due to intraparenchymal location. ${ }^{2}$

\section{Author contributions}

Carlos Almeida Jr., Jorge Alberto Martins Pentiado Jr.: study concept and design, drafting and revising the manuscript for content. Gisele Caravina de Almeida: acquisition of data, revising the manuscript for content. Richard Konichi Dias: acquisition of data, drafting and revising the manuscript for content.

\section{Study funding}

No targeted funding reported.

\section{MORE ONLINE}

$\rightarrow$ Teaching slides

links.lww.com/WNL/ A673

*These authors contributed equally to this work.

From the Departments of Neurosurgery (C.A.J.), Neuropathology (G.C.d.A.), and Neurology (J.A.M.P.), Barretos Cancer Hospital; and School of Health Sciences Dr. Paulo Prata (FACISB) (R.K.D.), Barretos, Sao Paulo, Brazil.

Go to Neurology.org/N for full disclosures. Funding information and disclosures deemed relevant by the authors, if any, are provided at the end of the article. 
Figure 2 Encapsulated cysticercus larvae stained in hematoxylin \& eosin (H\&E)

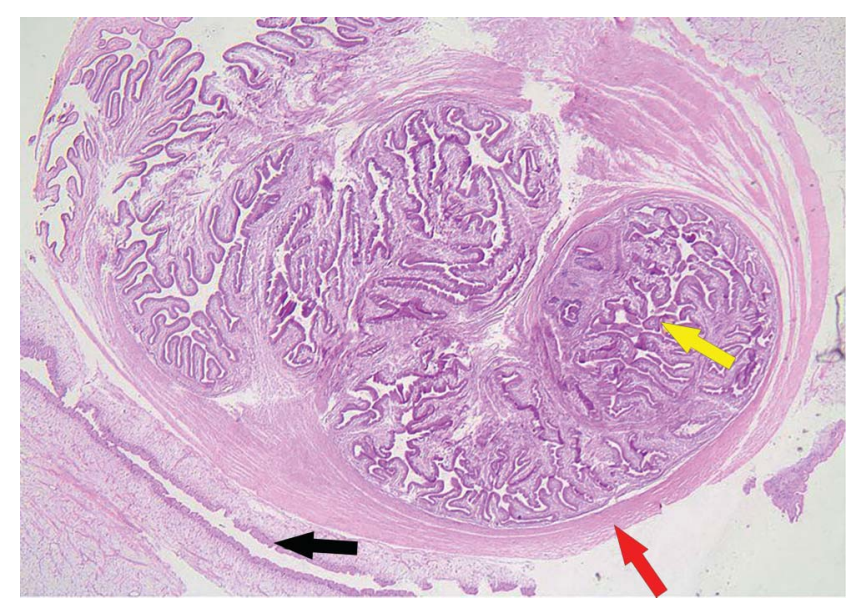

Histopathology shows encapsulated cysticercus larvae (H\&E, 40x). Outer membrane (black arrow), larval scolex (red arrow), and larval intestine (yellow arrow).

\section{Disclosure}

The authors report no disclosures relevant to the manuscript. Go to Neurology.org/N for full disclosures.

\section{References}

1. Chhiber SS, Singh B, Bansal P, Pandita KK, Razdan S, Singh J. Intramedullary spinal cysticercosis cured with medical therapy: case report and review of literature. Surg Neurol 2009;72:765-768; discussion 768-769.

2. Lucato LT, Guedes MS, Sato JR, Bacheschi LA, Machado LR, Leite CC. The role of conventional MR imaging sequences in the evaluation of neurocysticercosis: impact on characterization of the scolex and lesion burden. AJNR Am J Neuroradiol 2007;28: 1501-1504. 


\section{Neurology}

Teaching NeuroImages: Spinal intramedullary cysticercosis: The pseudotumoral form Carlos Almeida, Jr, Gisele Caravina de Almeida, Jorge Alberto Martins Pentiado, Jr, et al. Neurology 2018;91;e1202-e1203

DOI 10.1212/WNL.0000000000006206

This information is current as of September 17, 2018

Updated Information \& Services

References

Subspecialty Collections

Permissions \& Licensing

Reprints including high resolution figures, can be found at: http://n.neurology.org/content/91/12/e1202.full

This article cites 2 articles, 0 of which you can access for free at: http://n.neurology.org/content/91/12/e1202.full\#ref-list-1

This article, along with others on similar topics, appears in the following collection(s):

Clinical neurology examination

http://n.neurology.org/cgi/collection/clinical_neurology_examination MRI

http://n.neurology.org/cgi/collection/mri

Spinal cord infection

http://n.neurology.org/cgi/collection/spinal_cord_infection

Surgery/Stimulation

http://n.neurology.org/cgi/collection/surgery-stimulation

Information about reproducing this article in parts (figures,tables) or in its entirety can be found online at:

http://www.neurology.org/about/about_the_journal\#permissions

Information about ordering reprints can be found online:

http://n.neurology.org/subscribers/advertise

Neurology ${ }^{\circledR}$ is the official journal of the American Academy of Neurology. Published continuously since 1951, it is now a weekly with 48 issues per year. Copyright (O 2018 American Academy of Neurology. All rights reserved. Print ISSN: 0028-3878. Online ISSN: 1526-632X.

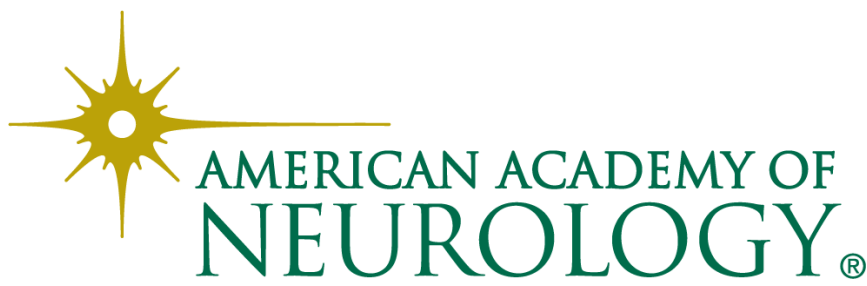

